eventually the mountant will be simple Canada balsam. If the slide is to be rung, it would generally be better to mount in the brom-naphthalene alone and thus obtain the advantage of a higher refractive index. Should, however, such a mixture be required, styrax, which is also soluble in mono-brom-naphthalene and has a higher refractive index than Canada balsam, would generally be a preferable ingredient. A workable combination has a refractive index of 1.62 .

In October of last year I carried out an investigation on the influence of the refractive index of mountants on biological tissues which I hope shortly to publish. Tissues were mounted in media of varying refractive index from $1 \cdot 34$ to $2 \cdot 1$ (phosphorus). The mountant of highest refractive index that could be conveniently used was a saturated solution of sulphur and arsenious sulphide in methylene iodide. Such a mixture is of a canary yellow colour and has a refractive index of 1.804. It is apparently stable, since it has been kept in an open test-tube, apparently unchanged, for five months. Mounts in this liquid, however, need ringing. A higher refractive index, namely, $1 \cdot 87$, is obtained with a solution of phosphorus in methylene iodide, but the golden yellow liquid soon becomes cloudy on exposure to air.

Pharmacological Laboratory,

Wilfrid Marghall.

University of Aberdeen, Mar. 4.

Isolation of the Radical Ethyl.

$W_{E}$ have been successful in preparing the free radical ethyl (in the same way as we obtained the free methyl) by decomposing lead-tetraethyl in a hydrogen stream at reduced pressure by means of heat (compare Paneth and Hofeditz, Ber. Deuts. Chem. Gesells., 62, $1335 ; 1929$. NATURE, 124,$161 ; 1929)$. The free ethyl is not less aggressive than the free methyl. It converts the metals zinc, cadmium, antimony, and lead into volatile compounds which (under atmospheric pressure and at room temperature) form limpid liquids. The zinc compound has been studied in some detail : the presence of ethyl could be established by converting the ethyl groups into alcohol and identifying the latter by the iodoform test; the metal revealed itself as zine free from lead, and the melting and boiling point of the compound coincided with those known for zinc diethyl. As the zinc metal before conversion into this compound had been located at a distance from the place of decomposition of the lead-tetraethyl, it seems to be demonstrated that the radical ethyl can be obtained in the free state and carried by a gas stream over several centimetres before recombination takes place.

A fuller report of the experiments on free ethyl will be published in the Berichte der Deutschen Chemischen Gesellschaft.

Chemisches Institut der Universität,

F. PANETH. W. LAUTSCH. Königsberg i. Pr., Mar. 17.

\section{The Maladaptation of Trout Spermatozoa to Fresh Water.}

The finding of Prof. Huxley (Nature, Mar. 29) that the addition of salts to fresh water prolongs the period of activity of trout spermatozoa confirms results of other workers. There are several papers bearing on this subject, but those of Scheuring 1,2 and Gaschott ${ }^{3}$ treat specifically of the spermatozoa of the trout and salmon. Analogous results have been obtained with amphibian material, and it is perhaps general that an osmotic pressure approximating to that of the tissues is favourable to the maintenance of the integrity of the cell, notwithstanding the fact that fertilisation may normally take place in a hypotonic medium. The problem is, however, not a simple one, and the specific effect of various solutes, more particularly their ions, on the cell must be taken into consideration.

Apart from the problems of physiological interest which are raised, the results have, as Prof. Huxley suggests, an interesting bearing on the evolution of species in their transition from marine to estuarine, fluvial, and terrestrial forms. The necessity for a reduction in the time of exposure of the gametes or their protection from the external environment is perhaps reflected in many modifications of sexual mechanisms and behaviour. Copulation with internal fertilisation is the most complete solution of the difficulty. At present I am collecting references and experimental data which I hope will enable me to write more explicitly on the subject in the near future.

School of Agriculture, Cambridge, Mar. 31.

1 Scheuring, L. Biologische und Physiologische Untersuchungen an Forellensperma. Arch. Hydrobiologie, Suppl. 4, pp. 181-318; 1925 2 Scheuring, L. Weitere biologische und physiologische Untersuchungen an Salmonidensperma. Zool. Jahrb., 45, pp. 651-706; 1928 3 Gaschott, $O$. Beiträge zur Reizphysiologie des Forellenspermas Arch. Hydrobrologie, Suppl. 4, pp. 441-478; 1925.

Mating during Pregnancy in the Mouse.

Ir would seem that mating during pregnancy in the rat and mouse is an exceedingly rare occurrence. Nelson (1929) ${ }^{1}$ has recorded one instance in the rat, and Long and Evans (1922) ${ }^{2}$ refer to two others. So far as we know, mating during pregnancy has not been recorded in the case of the mouse. It seems worth while to place on record, therefore, the following facts which have presented themselves to our notice during the course of an experiment in which 100 females have been examined daily for six months for vaginal plugs--evidence of mating. The animals were continuously kept with males so that every opportunity for mating was given.

\begin{tabular}{|c|c|c|c|c|}
\hline $\begin{array}{c}\text { Date when } \\
\text { 1st Vaginal } \\
\text { Plug was } \\
\text { noticed. }\end{array}$ & $\begin{array}{c}\text { Date when } \\
\text { 2nd Vaginal } \\
\text { Plug was } \\
\text { notjced. }\end{array}$ & $\begin{array}{c}\text { Date of } \\
\text { Parturition. }\end{array}$ & $\begin{array}{c}\text { Number } \\
\text { in Litter. }\end{array}$ & $\begin{array}{c}\text { Number of } \\
\text { Days between } \\
\text { 1st and 2nd } \\
\text { Vaginal } \\
\text { Plugs. }\end{array}$ \\
\hline 22.8 .29 & 7.9 .29 & 10.9 .29 & 4 & 16 \\
5.8 .29 & 9.8 .29 & 24.8 .29 & 6 & 4 \\
2.10 .29 & 12.10 .29 & 21.10 .29 & 8 & 10 \\
20.9 .29 & 5.10 .29 & 10.10 .29 & 8 & 15 \\
27.10 .29 & 5.11 .29 & 15.11 .29 & 8 & 8 \\
25.12 .29 & 8.1 .30 & 12.1 .30 & 5 & 14 \\
\hline
\end{tabular}

In our experience, then, out of 100 females under observation for six months, 6 presented trustworthy evidence that during pregnancy mating had occurred without in any way affecting the course of pregnancy. It is seen that during the course of a single pregnancy mating occurred only once in our experience, and that it occurred not always at the same time during pregnancy though always at a time when, had the animal not been pregnant, it would have been expected.

\section{F. A. E. Crew}

L. Miskaia.

1 Nelson, Warren O. CEstrus during Pregnancy. Science, vol. 70 No. 1819. Nov. 1929.

Long and Evans. The CEstrous Cycle in the Rat. Memoirs Univ. Calif., p. 58; 1922 .

No. 3154, VoL. 125] 